\title{
Vincent Price and Cult Performance: The case of Witchfinder General Justin Smith
}

\section{Introduction}

The key difficulty with the appellation 'cult' is that it remains in the gift of the giver and not the receiver. Cult is inescapably part of the discourse of reception studies, where it is couched as a floating signifier conferring status through a shared, though seldom well-defined, understanding. Concerns about cult appreciation as sub-cultural practice have, therefore, tended to overshadow the necessary examination of texts (films, directors, actors). The critical task must be to see if it is possible to find textual evidence for cult affiliation.

This chapter aims to identify certain attributes of cult performance as evidenced by Vincent Price, in a case study of Matthew Hopkins, Witchfinder General (1968). It proposes that the circumstances of this film particularly drew a performance from Price which reveals a kind of vulnerability which is at odds with his role as the eponymous witchfinder, in this English Civil War revenge horror. Andrew Klevan writes:

A film may look to have a straightforward plot that determines the direction of the drama. Yet a performance within a film can tell a different story. Our appreciation of a performance may encourage us to reorganise a film's elements and shift our perspective on the action, and this may in turn unlock qualities in a film that appears limited without such an appreciation. (Klevan, 2005: 77) 
Here I argue that Price's performance in Witchfinder General points to just such ambiguities, and invites counter-intuitive readings of a kind which might attract cult appreciation. This chapter further suggests that the textual evidence of cult performance may be seen, in part, to have been determined by extra-textual factors: Price's relationship with novice British director Michael Reeves, and the actor's own career trajectory.

At the outset it is necessary to establish distinctions between three related levels of analysis in this field: star persona, acting and performance. As Baron and Carnicke note: "The perceptible details of screen performance come into view more readily when they are differentiated from fictional characters, actors, and stars" (Baron and Carnicke, 2008: 62). This chapter will therefore begin by considering Vincent Price's cult persona as an essential part of his star image, drawing on popular critical and fan sources. It will then compare Price's working relationships with directors Roger Corman and Michael Reeves, using published interviews and scholarly accounts. Finally, Price's performance as Matthew Hopkins in Witchfinder General will be the focus of textual analysis; an interpretation will be offered which highlights the ways in which the central performance transforms the revenge narrative of this period horror.

\section{A Cult Star}

Vincent Price's cult following is indisputable, on the evidence of a host of fan-made websites and special issue tributes, in-depth interviews in cult journals such as Cinefantastique, Fangoria and StarBurst, and latter-day 'celebrity' appearances in Michael Jackson's Thriller (1983) and Tim Burton's Edward Scissorhands (1990). Since the actor's death in 1993, reappraisals of his career have drawn attention to the 
range of his film and television work, and his private passions for art and food. He has also become a gay icon, as Benshoff's (2008) work reveals. Yet there seems to be broad consensus that Price's cult star reputation rests upon his low-budget horrors made for American International Pictures (hereafter AIP) between 1960 and 1973. The fact that many of these films were originally promoted in comic book versions suggests that their target audience and cult potential were envisaged in the marketing strategy from the outset. A contemporary interview with Price for Films and Filming noted that "in recent years he has been more closely associated with the 'horror' film ... earning titles for himself like 'The Merchant of Menace'” (Anon, 1965: 5). A late interview conducted by Wheeler Winston Dixon sought to re-focus attention upon the actor's "non-horror" work, since "Price has been firmly 'typed' ... as a Gothic villain ... and has grown tired of discussing his work with Roger Corman” (Dixon, 1992: 12).

There is also general agreement in popular criticism about Price's performance style across this body of work, by turns described as: "cultivated", "camp", "selfconscious", "over-the-top", and "tongue-in-cheek" (see especially Biodrowski et al, 1989). One fan site offers this characteristic summary: "Known for his distinctive, low-pitched, creaky, atmospheric voice and his quizzical, mock-serious facial expressions" (http://www.vincent-price.net/index.htm). There are several sites dedicated to audio clips celebrating the sound of Price's voice (for example The Sound of Vincent Price, and The Pit). It may simply be that Price's famously hammy histrionics invite that familiar subversion of qualitative hierarchy upon which much cult appreciation rests: it's so bad it's good. Slant Magazine's review of MGM's Scream Legends 2007 DVD box-set of Vincent Price is characteristic of popular criticism: "Price had a way of turning horror into a winking act conspiratorially 
shared with audiences, summoning a genuine gothic theatricality while slyly lampooning it" in a "mix of overripe dramatics and wily humour" that was "camp before its time" (Croce, 2007). It is tempting to regard these comic horror parodies, for which Price is best known, as examples of exploitation genre hybridity, where cult attention is also most frequently focussed.

In this way a star's performance style (especially in the case of genre actors like Price), can be seen as supra-textual, existing as an agglomeration of a number of similar performances condensed and abstracted from the particularities of his different film roles. This, indeed, may be a caricature, or an iconic manifestation, of his actual, varied performances. Baron and Carnicke warn that "analyses of screen acting are complicated by the fact that extra-textual information colours audience responses to performances". Thus:

with the cultural image of the celebrity or genre star defined well in advance, fans enjoy a particular performance because it meets their expectations, while critics often dismiss performances by celebrities and genre stars as instances of personification, when performers simply play themselves. (Baron and Carnicke, 2008: 67)

Indeed, Price's 'type-cast' horror work has been subject to just such reductive reception discourses as a function of his star persona. And it is arguably through such caricatures that his cult star status endures. But in order to find evidence of cult performance, we must attend to Price's work as an actor in specific historical examples.

\section{Relationships with Directors}


Carnicke's studies (Carnicke, 2004: 42) show "that screen actors accommodate different directorial visions by adjusting their performances to suit the aesthetic and narrative styles of the films in which they appear". These accommodations depend upon the recognition that directors are actors' "primary source of feedback" in performance, and that directors "affect performances by contributing to decisions about what will be seen in the completed film" (Ibid.: 43). In this way:

Whatever the working relationship between actor and director during filming might have been, the performance seen in the final cut is assembled by selecting those performed moments in which actors' physical and vocal expressions best embody the film's underlying themes and aesthetic style. (Ibid.: 45)

It should be noted that the production constraints upon low-budget, genre film-making alter nothing about the terms of this fundamental relationship between actor and director, though they may affect the quality of the work. We should also be mindful, in the production history which follows, of the discursive formation of actors' and directors' testimony, whether in private correspondence, personal exchange or published interview, when evaluating its worth.

\section{(i) Price and Corman}

Although he had starred in horror films since House of Wax in 1953 - notably William Castle's House on Haunted Hill (1958) and The Tingler (1959) - the films he made for AIP with Roger Corman between 1960 and 1964 have, as noted above, come to typify Price's horror career and characterise his star persona. These were, at best, loose adaptations of Edgar Allen Poe's work; but AIP allowed Corman free rein and, 
by their standards, advantageous terms. House of Usher (1960), which began the series, was accorded "a three-week schedule and a $\$ 270,000$ budget, rather than the usual two weeks and \$150,000", and it earned over \$2million at the US box office (Biodrowski et al, 1989: 52-54). Driven by this immediate success, the formula was repeated with The Pit and the Pendulum (1961). Thereafter, tongue-in-cheek humour increasingly inflected these gothic melodramas. The compendium film Tales of Terror (1962), and The Comedy of Terrors (1963) were directed by Jacques Tourneur and co-starred Boris Karloff, Peter Lorre, and Basil Rathbone. Corman returned to direct another tenuous Poe adaptation, The Raven (1963), in which the cast was the same and the comic elements became increasingly self-indulgent. Price recalled: The original script for The Raven was supposed to have comic overtones; that is, it was a lot straighter than it finally finished up. And Boris, Peter and I got together and decided that it didn't make any sense at all. So then we all sort of dreamed up the broader laughs. (Austen, 1969: 53)

Despite the unevenness in the quality of their output, one of things which characterised Price's working relationship with Corman at AIP was consistency. Screenwriter Richard Matheson, production designer Danny Haller, AD Jack Bohrer, DP Floyd Crosby and costume supervisor Marjorie Corso were all regulars on these Poe adaptations. Moreover Price, like Corman, felt at home in the studio. $\mathrm{He}$ reflected: "I think that when you're trying to make people believe, then it's terribly important for these films to have an element of 'make-believe' about them ... and you can only get that in the studio" (Ibid.). Arguably, the formulaic nature of their product suited both men. Price was a literal-minded actor, who required a sense of the story and of character motivation. Corman was a scenarist who worked almost 
exclusively in the studio, and whose pre-shooting 'rehearsals' amounted to blocking out each set-up. In an interview in 1965 Price revealed:

Where Roger and I have worked well together has been in the fact that I am a terrible stickler for explanations ... Why does a man do something? What should the audience know, see, feel? ... Roger is a director who loves to create a mood. (Price, 1965: 6)

Their responses to Poe were also different, though complementary. Price's faith rested with the source in his work on these films: "The closer they stick to Poe and to the basic motivations of the characters, obviously the better they get (some have been really way out)" (Ibid.). Corman, by contrast, "was interested in all sorts of Freudian implications". Price recalled: "Roger's theory was that Poe was, to a great degree, working out of his subconscious mind" (Biodrowski et al, 1989: 63).

In this way, Price's literal interpretation was sublimated by Corman's visual imagination. As a consequence, it is possible to discern a tension between the narrative and visual discourses in the films. And Price's performances are shot through with this tension, because he was a remarkably self-conscious actor, aware of his own performance and of the ideas about the character he was trying to communicate. That said, there was a mutual respect between the men, and Corman was not a demonstrative director. He allowed Price room to express himself - not least in the scripts - but also offered him the guidance he required. The same could not be said of the relationship between Price and the twenty-four year old British director Michael Reeves, on Witchfinder General.

\section{(ii) Price and Reeves}


Following Corman's departure from AIP, where Price remained under contract, the actor featured in a ramshackle assortment of co-productions arranged by Louis $\mathrm{M}$. ('Deke') Heyward, AIP's Director of Overseas Productions. They ranged from the modishly sixties, sci-fi sex comedy Dr. Goldfoot and the Bikini Machine (1965), and an even worse sequel directed by Mario Bava, to a fantasy adventure City Under the Sea (1965) and a lamentable western, More Dead Than Alive (1968). Heyward's brief was also to find European exploitation product to sell in the US, and it wasn't long before he formed an association with Tony Tenser, whose Tigon British Productions sold him, amongst others, The She Beast (a horror starring Barbara Steele made in Italy in 1965) which was Michael Reeves' first feature. Reeves had a screenplay of a novel by Ronald Bassett about the East Anglian witch trials of the Seventeenth century, and wanted Donald Pleasence to play the titular Matthew Hopkins, Witchfinder General. However, Tenser did a deal with Heyward in which AIP would contribute $£ 32,000$ of the film’s $£ 83,000$ budget, and provide their contract star Vincent Price to take the lead. Reeves was furious, considering Price altogether inappropriate for his vision of Hopkins. "I'm saddled with Vincent by American International", the director complained to his friend Jack Lynn (Halligan, 2003: 118). But the terms were agreed and the film green-lit.

The feud between the young director and his experienced star continued during the whole shoot, which took place on location in East Anglia. Halligan captures the director's particular disappointment:

He wanted acting, not camping; the film needed a "hard performance" not the kind of grandstanding Price usually passed off for AIP, where he seemed to both act the part and act out caricatured audience responses to the horrors. (Ibid.) 
Whilst Halligan's view may be an accurate interpretation of Reeves' frustrations, it also invokes some of the familiar vocabulary of critical discourse around Price's performance style. Other accounts show that Price was equally frustrated. For Price, Reeves “was very difficult to work with because he didn't know how to tell an actor what he wanted" (Dixon, 1992: C15). The veteran star told Cinefantastique:

"Afterwards, I realized what he wanted was a low-key, very laid-back, menacing performance. He did get it, but I was fighting with him almost every step of the way. Had I known what he wanted, I could have cooperated" (Biodrowski et al, 1989: 69). Price complained: “He'd come to you and say the one thing you shouldn't tell an actor that gives him no security at all. We didn't get on at all. He would stop me and say 'Don't move your head like that'!" (Ibid.). Sam Arkoff, surprisingly, held a more generous view: "Michael Reeves brought out some element in Vincent that hadn't been seen in a long time. Vincent was more savage in that picture. Michael really brought out the balls in him" (Ibid.).

Whatever the veracity of these anecdotes and memories, the fundamental antipathy of the two men was evident. By his own admission, Price had required character psychology from Corman. But for Reeves "the interest and depth of the film was to be found in the action, in the wider aesthetic considerations, rather than the evolving psychological dimensions" (Halligan, 2003: 120). His direction of Price constantly emphasised the need for physical containment and minimal gestures $-\mathrm{a}$ significant alteration from the grand guignol theatrical style which typified his expressive, melodramatic performances for Corman. Given the ongoing antagonism between them then, it is remarkable that Price gave a more genuinely malevolent and controlled performance than anything he had previously done. Arguably, it also 
realised Reeves' vision of Hopkins in a more profound manner than he might have hoped, as the following analysis will show.

\section{Performance Style}

Before examining Price's performance, it is important to establish the narrative structure of the film and its central themes. It is likely that Reeves really sought in Price's Hopkins a mythic figure, rather than a character study, in order to advance what he conceived of as an English western. Certainly the film is structured along the lines of a revenge western, and Reeves' co-writer, Tom Baker, commented that "from the start we wanted movement across the landscape and across the country to be a strong theme" (Ibid.: 110). In this way, location shooting gave Reeves and Baker a historical and geographical terrain onto which they mapped a western outline. The conception of the East Anglian witch hunts within a western framework reveals not only Reeves' awareness of common patterns in the signs and symbols of ritual and myth, but acts as a structuring device for dramatising a society riven by degenerative (male) violence. Moreover, both the western and horror are genres predicated on the expository stance that law and order has collapsed. But as Halligan points out, where blood-letting and civil strife in Peckinpah leads to "a rediscovery and reaffirmation of masculinity, for Reeves it leads only to insanity" (Ibid.: 180).

Alan Macfarlane (1970), in his extensive study Witchcraft in Tudor and Stuart England, sets out two related historical explanations of witchcraft practices. First he describes a functionalist approach which posits witchcraft practices as providing a socially recognized channel for the culturally disallowed, a displacement for taboos. But secondly, he interprets witchcraft functioning as a structural system for expressing tensions between ideals and practices within the social group. There is a 
useful correlation here with the filmic narrative's placement of females as essentially 'other' and thus problematic. The structural dialectic played out here is between the approved roles accorded woman within the society, and the policing of deviance. Witchcraft is thus constructed as a structural mythology for both isolating and eliminating the 'problem'. Such ingrained misogyny however, is never rationalised within the film. Importantly, there is no 'evidence' presented about any woman accused. The choice of victims appears either indiscriminate or buried within the undisclosed prejudices of the village community. While we are encouraged to feel sympathy (and their innocence is never in doubt), the film allows no explanatory payoff or the possibility of comprehensive justice. Indeed, there is no witchcraft in the film, and nothing of the supernatural at all. Rather, the structural discourse of witchcraft is Hopkins' (and Reeves') pretext for legitimating misogyny and violence.

Like the western, the territory of Witchfinder General is almost exclusively male. Women have little to say and there are no conversations between women, only through men. Like the western too, once the chase has been set (upon Marshall's discovery of his sweetheart's violation at the hands of Hopkins and Stearne) there is not only a tragic inevitability about its course, but also a sense of equanimity between pursuer and pursued. They are bound not only by their gender but their will-toviolence as a method. Significantly, Marshall becomes inchoate with rage and psychotic in his final axe-attack on Hopkins. As Swallow (Nicky Henson) bursts in and shoots Hopkins to cease the butchery, Marshall's anguished repetition of "You took him from me!" is charged with a homoerotic lament for their broken union.

The main female character provides the perfect illustration of misogyny as a structuring device in the film. Sara (Hilary Dwyer), niece of the accused pastor of Brandeston, John Lowes (Rupert Davies), is presented as problematic, not just to 
Hopkins and his henchman Stearne (Robert Russell), but significantly to her betrothed, Richard Marshall (Ian Ogilvy). As Peter Hutchings has indicated, "she is surrounded by men who objectify her in various ways" (Hutchings, 1993: 149). Thus, the film (and by implication the society from which it comes) refuses to permit the existence of woman-as-subject until the very end where Sara's last tortuous scream echoes in freeze-frame as the credits roll. It is that anguished cry that we are left with as the articulation of womanhood. "The despair of the conclusion", Hutchings writes, "in this sense arises from an inability to go further, to put something else, something more positive, in its stead" (Ibid.: 150-1). In his incisive account, he considers that the film's thesis is thus flawed because it fails to offer closure, either in a reactionary re-objectification of woman (as in classic Hammer horror) or in some new liberated form. Sara's despair can be seen in this way as the despair of the filmmaker himself and, indeed, a universal, existential cry. As such, the narrative comes close to endorsing the problematizing of woman (while rejecting the 'solutions' of either Hopkins or Marshall) through the absence of resolution and a denial of any meaningful catharsis. But how is this impasse arrived at?

Cinéfantastique's in-depth tribute to Witchfinder General points out that the filmic narrative offers to the audience no one character with whom to align sympathy or engage point of view (Kelley, 1991b: 40). This structural objectification of the audience's view has particularly important implications for the way in which the film is read. Central to this narrative technique is what I would term a tableau effect, wherein the dynamics of character identification play inside and out (across a structural dynamic) of the conventional dichotomies of hero and villain, creating a disquieting disruption of viewpoint. What might otherwise pass for a rather stilted 'staginess' elevates certain scenes to a symbolic order redolent of Ancient Greek 
theatre, yet without implicit moral encoding. Witness, for example, Sara's willingness to offer herself sexually to Hopkins in a wanton manner which exceeds dramatically the psychological motive of sparing her uncle. The production's Press Book describes Sara "sensing Hopkins' inherent sexual inadequacy” (1968). There is a marked stylistic contrast between Price's physical dominance on horseback, and such rare scenes of intimacy where his patriarchal authority seems threatened. Like the western hero, he is out of place in domestic interiors. Halligan notes that "he dwarfs some of the rooms in which he is seen" (2003: 175). This is both a function of shot composition, which conveys visually his relative power and position, but also his physical awkwardness in interior spaces. Indeed, as the following analysis will show, Price's performance orchestrates the structural antinomies of power/vulnerability across Reeves' tableau method.

As the film's central character, driven to do God's work by pursuing and persecuting witches, Price/Hopkins' impassivity and reserve combine pathological calculation with an aristocratic bearing. His predetermined orders and unruffled responses to the unexpected serve to foreclose disruption and abdicate him from the chaos he fuels. His dirty work is performed throughout by his sadistic sidekick Stearne, ensuring Hopkins keeps his hands clean, distancing himself from the violent action he orchestrates. In this way he might almost be said to occupy a directorial position within the narrative. He is at its magnetic centre, and evinces a charismatic power, through his physical presence and its framing: "The camera constantly films Price from a low-angle, grimace on his face - an unstoppable bringer of death, looming across the screen, a character defined solely by his function (Ibid.: 176). Moreover, Price's demeanour, facial expressions, gestures and gaze, not only police the filmic world, but seem to offer an internalised commentary upon the action. 
It is this combination of explicit authority and implicit emotional register which renders Price's Hopkins a captivating creation, a mesmeric figure whose presence transcends the narrative action as in some medieval religious tableau. It is worth enumerating the patterns of gaze in particular to clarify this point.

\section{INSERT STILLS SET HERE}

\section{Caption: Gaze patterns in Vincent Price's performance in Witchfinder General [Prism DVD, 2003]}

This repertoire is based upon the repetition of what we might call certain 'stock' looks. The effectiveness of these for Price depends largely upon the poise of the head, a rather quizzical furrowing of the brow, the narrowing of the eyes and the angle of eye-line. Frequently captured in medium close-up, occasionally in extreme close-up, the camera invariably views Hopkins from low-angle, emphasising his stature. The staged persecution scenes cut between depiction of the acts themselves and reaction shots. Hopkins has most of the reaction cutaways here, since he is not merely reacting but orchestrating these hideous events. It is instructive to note, for example, that in the ducking scene set against the impressive backdrop of Kentwell Hall, an Elizabethan manor house in the remote Suffolk village of Long Melford, there are no fewer than nineteen cutaways to Hopkins in a scene of two minutes duration. This means he is framed in medium close-up on average almost every six seconds. On occasion also, the camera lingers or zooms in to extreme close-up on the face of Price beyond the necessity of dramatic convention, as if searching for explanation in his largely inscrutable visage, or dwelling fetishistically on this personification of evil. These performance effects are achieved through a 
combination of Price's physical bearing and facial expressions, and framing and editing decisions. It serves to heighten the intensity of the violence, and to position Price's Hopkins at its centre.

Many of Price's head and eye angles cross the picture plane at about 45 degrees, rarely more or less. This of course presents evasion and sinister mystery. These eye-lines however are often combined with two kinds of throwaway look, either downward into obscurity or away into an invisible distance, suggesting mute contemplation. This combination of focal length, head angle, eye-line and aperture lend Price a mesmeric quality. It is as if he were internalising the violence he has unleashed and reflecting upon its moral purpose.

As important as patterns of gaze to the impact of the tableau effect is also the related vocabulary of spatial interrelations. This is the filmic ground where physical communication takes place across the lexicon of body language, gesture and poise. This is a process of three-way interaction of course, since it is resolved not only between figures on screen caught in physical relation to one another, but also between the picture plane and the spectator in the poetics of camera angles and focal lengths. If one can posit a cinematic equivalent for the inter-personal and socio-psychological awareness of private and public space, physicality and gesture, then this film continually infringes beyond the boundaries of conventional social space. This is another measurable aspect of its transgressive nature. It dramatises the invasion of personal spaces both between characters in unconventional proximity and by eccentric attention to (the fetishizing of) the film plane from the spectator's point of view.

Leon Hunt points to our first glimpse of Hopkins, silhouetted on horseback in the title sequence, where "we are denied Price as spectacle; instead, he is presented as a tiny, silent figure, strangely removed from the action" (Black, 1996: 128). This 
sense of Price being both at the centre and at the margins of the violence he orchestrates stands as a physical manifestation of his moral ambivalence, rather like the ubiquitous yet elusive 'man with no name' in Sergio Leone's spaghetti westerns. But the same divisions in Hopkins' nature are figured also in attention to small details in the interior scenes. In the seduction of Sara, Price does strange things with his hands, unbuttoning her nightdress with all the dexterity of a fumbling schoolboy, arching his wrists in effeminate flamboyance. Indeed, throughout, Price conveys much with his hands, emphasising symmetry and control when gripping the reins on horseback or hooking his thumbs into his belt; yet his spatulate fingers are oddly tentative and sensual in the tactile discovery of new surfaces: Sara's nightgown, the mattress of his bed at Lavenham. These minimal gestures are part of a lexicon of containment which emphasises a reluctance to get to grips with the 'foreign', to come into contact with that which is 'other', as if in fear of contamination. He is able to delegate the necessary physical engagement to the brutally hands-on Stearne, of course. In the Lavenham interior scene, with the eager town Justice, Master Webb, Hopkins is sitting on his bed in the foreground, unbuttoning his tunic. This undressing in its promixity to the viewer feels odd, almost as if he were exposing his nakedness to us, though he doesn't remove so much as his shirt. It is a moment of disturbing intimacy. Examples in this play of proximity and distance work across an opposition of attraction/repulsion, of what is at once compelling and repugnant. How are we to interpret this performative trope? Recourse to theory may be useful here.

In Arthur Frank's typology of body use in action, he defines the "dominating body" as "constantly aware of its own contingency":

The essential quality of these bodies is their construction of desire as lack, a lack which demands compensation. Combined with the body's 
dyadic other-relatedness, the dominating body's lack produces a fear which is turned outwards on others who are exterminated in order to combat that fear ... Finally, the dominating body must be dissociated from itself in order to punish and absorb punishment. Dominating bodies are overwhelmingly male bodies. (Shilling, 2003: 85)

What could pass in this sociological study for a description of Hopkins' physical persona in Witchfinder General (notably its "self-dissociation"), also finds echoes in the social study of charisma in Dyer's reading of Max Weber. This offers us some useful signposts as to how charisma might actually work in popular film performance. Dyer, following Eisenstadt's interpretation of Weber, suggests that star charisma in films might be conceptualised "in terms of the relationships between stars and specific instabilities, ambiguities and contradictions in the culture (which are reproduced in the actual practice of making films and film stars)" (Gledhill, 1991: 58). In this model, according to Dyer's reading of Eisenstadt, charismatic appeal may be "effective when the charismatic figure or group offers a value, order or stability" as reassurance in times of social upheaval (Ibid.). Yet here Price's dominating body is a destabilizing force which exposes in performance its own lack, its own vulnerability.

Key to this notion, in Witchfinder General, is the persuasive sense that Hopkins, like Milton's Satan, is a compelling villain. Through the visual and emotional intensity (and vulnerability) of his screen persona an audience is seduced in spite of the repugnance of his activities. If we can speak in terms of a cult 'look', then this is it, in all its seductive power. And much of its magnetism is also signified in the vocal register and tonal qualities of Price's delivery. His theatrically urbane American accent, a slow, almost caressive, certainly hypnotic delivery, and a fleeting 
smile, lend Hopkins a charismatic authority in excess of the narrative realism of this very English picture. Ultimately what makes this performance so powerful is its moral ambiguity, located within a genuinely violent historical narrative which offers none of the recuperative comfort (or comic relief) of gothic fantasy.

The reason that Price's performance is so compelling is because it is so obviously a performance - as if this demonic figure were wrestling with his own divided self. His physical presence and narrative dominance are delimited by curious lapses and evasions which provide a vocabulary of authority/vulnerability. This carries a moral charge through the external commentary Price appears to offer in moments of dissociation. In this way he embodies the profound divisions which are at the dark centre of this film. His charismatic power is rooted in his ambivalent attitudes to sexual difference and his transgressive role as malevolent patriarch - a 'bad father' figure. His self-conscious sense of contingency in performance carries with it an anxiety and vulnerability which is, arguably, compelling.

\section{Conclusion}

This was a violent and revolutionary moment. Witchfinder General was released in Britain on 19 May 1968 as students took to the streets of Paris and 25,000 antiVietnam war protesters gathered in Grosvenor Square, London. In the same year, that other dark paean for the counter-culture, Performance, was completed. Jean-Luc Godard came to Britain to make One-Plus-One (Sympathy for the Devil) with the Rolling Stones. Satanism hit the headlines in an establishment moral panic.

At least part of the emerging counter-cultural discourse was expressed through a fascination with paganism and the occult, from the Stones' Their Satanic Majesties Request (1967) to hippy environmentalism and back-to-nature rhetoric, from the 
deification of Aleistair Crowley to the avant garde films of Kenneth Anger. As Leon Hunt writes, "the growing interest in paganism was partly bound up with uncovering a more 'authentic' national identity and culture" and further, became "a way of talking about the relationship between the upheavals of the late 1960s... and the backlash of the 1970s" (Chibnall and Petley, 2002: 92-3).

Steve Chibnall suggests that as far as British film culture of the period was concerned, the revolutionary moment "tended to be displaced into the domain of allegory where it found [in] the horror film...the most important site for the allegorical exploration of the struggle between the emergent discourses of radical change... and the beleaguered discourses of reaction" (Chibnall and Petley, 2002: 159). Witchfinder General's unfettered violence and misogyny might be read as one such response to contemporary events.

Price himself was frequently affronted by his treatment on this film and threatened to walk out; yet he later claimed it, rightly, as one of his best roles. Perhaps cult fans identify with those charismatic performances which offer both stimulation and solace, and those actors who are capable of pretending, with heavy irony, that they are just playing a part. In cult performance the thrill is in being able to see the acting happening. In this case this double articulation in Price's Matthew Hopkins also has a moral weight: it reveals a divided self at the heart of Hopkins' violence. In terms of star persona it also reassures us that beneath the surface the icon is vulnerable, just like us; like us, they don't fit in.

In this way Price's cult appeal in Witchfinder General could also be interpreted as an expression of the actor's own increasing alienation - an awareness of not fitting-in. Performance style is culturally grounded. There are fashions in screen acting of course, but there are also broader trends in changing social codes of 
behaviour, deportment, gesture and speech. Price's style, always conspicuous and idiosyncratic, perhaps appeared increasingly dissociated from the late 1960s, as gothic horror gave way to more explicit contemporary realism in the exploitation market.

The sense of a worn out formula is evident in The Oblong Box (1969) and Cry of the Banshee (1970). Both were directed by Gordon Hessler, who lamented the limited opportunities such poor scripts offered to Price: "Vincent's become almost a caricature of himself" (Biodrowski et al, 1989: 72). Rick Worland considers that Robert Fuest's Dr. Phibes comic horrors which followed were "less a parody of the genre than a riff on Vincent Price's star image" (Worland, 2003: 21). In Theatre of Blood (1973) Price's demented impresario, as in many of his later screen roles, is so framed by its own narrative function as staged performance, that issues of quality are almost elided.

But more is at stake here, regarding the matter of cultural capital. Worland's interesting pursuit of Price's private passions as an "art critic and collector, author, raconteur, and gourmet chef" posits a "juxtaposition of this cultured public image with Price's almost exclusive dedication to exploitation horror roles" (Ibid.: 23). For Worland, his "camp appeal" derives in part from this on-screen/off-screen contradiction. Yet it is also possible to view Price's persona as a product of an unresolved tension between his high cultural aspirations and his career in low-budget exploitation films. Price always talked seriously about literature, seriously about art and seriously about the profession of acting. Arguably, his personal cultural capital failed to find secure investment in the cinema. Certainly, as the high Sixties gave way to more extreme films and outlandish roles, Price seemed increasingly to be going through the motions: doing 'Vincent Price' again. 
But Witchfinder General was a serious horror film, and arguably Price's finest screen performance. Here, in Dyer's words (Gledhill, 1991: 58), "specific instabilities, ambiguities and contradictions in the culture" seem to be written large in Price's performance: about patriarchy, violence, generational divisions and codes of masculinity. Here, beneath Hopkins' demonic power, Price's charismatic vulnerability is so clearly exposed. This dynamic is what gives the performance its cult appeal.

This chapter is dedicated to the memory of Robert Walinski-Kiehl.

\section{Bibliography}

Austen, David (1969) 'Black Cats and Cobwebs', Films and Filming 15 (11), (August), pp. 52-4.

Baron, Cynthia and Sharon Marie Carnicke (2008) Reframing Screen Performance. Ann Arbor: University of Michigan Press.

Benshoff, Harry M. (2008) 'Vincent Price and Me: Imagining the queer male diva', Camera Obscura 6723 (1), pp. 146-50.

Biodrowski, Steve, David Del Valle and Lawrence French (1989) 'Looking Back on Forty Years as Horror's Crown Prince', Cinefantastique 19 (1/2), (January), pp. 40-85, 119-120.

Brottman, Mikita (1997) 'Ritual, Tension, and Relief: The Terror of "The Tingler", Film Quarterly 50 (4), pp. 2-10.

Carnicke, Sharon Marie (2004) 'Screen Performance and Directors' Visions', in Cynthia Baron, Diane Carson and Frank P. Tomasulo (eds), More Than a Method: Trends and Traditions in Contemporary Film Performance. Detroit, Michigan: Wayne State University Press, pp. 42-67.

Chibnall, Steve (2002) 'A heritage of evil: Pete Walker and the politics of Gothic revisionism', in S. Chibnall and J. Petley (eds), British Horror Cinema. London: Routledge, pp. 156-171. 
Croce, Fernando F. (2007) Review of Vincent Price: MGM Scream Legends Collection. Slant Magazine, 28 September 2007. Available at: http://www.slantmagazine.com/dvd/review/vincent-price-mgm-scream legends-collection/1218 [Accessed: 21 January 2012].

Dixon, Wheeler W. (1992) 'The Other Side of Vincent Price: An interview', Classic Images 204 (June), pp. C12-15, 35.

Dyer, Richard (1991) 'Charisma', in Christine Gledhill (ed), Stardom: Industry of Desire. London and New York: Routledge, pp. 57-59.

Gaskill, Malcolm (2005) Witchfinders: A Seventeenth-Century English Tragedy. London: John Murray.

Goffman, Erving (1959) The Presentation of Self in Everyday Life. Harmondsworth: Penguin Books.

Halligan, Benjamin (2003) Michael Reeves, British Film Makers series. Manchester, MUP.

Hunt, Leon (1996) 'Witchfinder General: Michael Reeves' Visceral Classic', in Andy Black (ed), Necronomicon: Book One. London: Creation, pp. 123-30.

Hunt, Leon (2002) 'Necromancy in the UK: witchcraft and the occult in British horror', in S. Chibnall and J. Petley (eds), British Horror Cinema. London: Routledge, pp. 82-98.

Kelley, Bill (1991a) 'Michael Reeves - Horror's James Dean', Cinéfantastique 22 (1), (August), pp. 33-38, 43-45.

Kelley, Bill (1991b) 'Witchfinder General', Cinéfantastique 22 (1), (August), pp. 3942.

Klevan, Andrew (2005) Film Performance: From Achievement to Appreciation. London: Wallflower.

Matthew Hopkins Witchfinder General Press Book, 1968 (held at the BFI library, London).

Macfarlane, Alan (1970) Witchcraft in Tudor and Stuart England. London: Routledge \& Kegan Paul.

McNally, Judith (1974) 'Lucrative Trash - The Dime Store Movies', Filmmakers' Newsletter 7 (12), (October), pp. 61-63.

Munro, Caroline (2005) 'Looking Back with Caroline...', Cinema Retro 2 (May), pp. $60-61$.

Pendleton, Thomas A. (2001) 'What (?), Price (?), Shakespeare (?), Literature/Film 
Quarterly 29 (2), (August), pp. 135-146.

Price, Vincent (1965) 'Mean, Moody and Magnificent, An Interview with Vincent Price', Films and Filming 11 (6), (March), pp. 5-8.

Shilling, Chris (2003) The Body and Social Theory, $2^{\text {nd }}$ edn. London: Sage.

Svehla, Gary J. and Susan Svehla (eds) (1998) Vincent Price. Baltimore: Midnight Marquee Press Inc..

“The Pit!”. Available at: http://www.seahaas.com/thepit/price.html [Accessed: 26 January 2012].

"The Sound of Vincent Price". Available at: http://www.thesoundofvincentprice.com/ [Accessed: 26 January 2012].

"The Vincent Price Exhibit". Available at: http://www.vincentpriceexhibit.com/

[Accessed: 23 January 2012].

"The Vincent Price Website". Available at: http://www.vincentprice.org/ [Accessed: 23 January 2012].

Theobald, Robin (1975) Charisma: some empirical problems considered, Research Paper No.5. London: Polytechnic of Central London School of the Social Sciences and Business Studies.

"Vincent Price". Available at: http://www.vincent-price.net/index.htm [Accessed: 21 January 2012].

Wood, Robin (1969-70) 'In Memorium Michael Reeves', Movie 17 (Winter), pp. 2-6.

Worland, Rick (2003) 'Faces Behind The Mask: Vincent Price, Dr. Phibes and the horror genre in transition', Post Script 22 (2), (January), pp. 20-33. 